\title{
Thermophysical Properties of Hybrid Nano Fluids
}

\author{
Sandeep Chinta, Sakkirga Mounika, Aravind Reddy
}

\begin{abstract}
In this study, the ash from agriculture waste of bamboo leaves was used in the synthesis of silica nano particles followed by leaching and acid treatment. The required ash from agriculture waste (bamboo leaves) is subjected to sintered at 700 degree centigrade for 5 hours to eliminate residues from ash. The obtained powder was treated with $1 \mathrm{M} \mathrm{NaOH}$ for leaching and then acid- treatment with $0.5 \mathrm{M} \mathrm{H} 2 \mathrm{SO} 4$ to precipitate pure $\mathrm{SiO} 2$ nano particles powder. The synthesized silica were characterized by XRD, FTIR, SEM, PSA, ZETA POTENSIAL. And the synthesis of $\mathrm{CuO}-\mathrm{SiO}_{2}$ hybrid nano fluid from the agriculture waste of silica.
\end{abstract}

Keywords : Particle size analysing, copper oxide, XRD, SEM, FTIR, silica, sulphuric oxide, Nano particles.

\section{INTRODUCTION}

Basically nano fluids are used for heat transfer. Understanding is very important while transferring the heat exchange. The research of the nano fluids (or) nano particles is very important. The understanding of the nano fluids mechanism in heat transfer makes promising the heat transfer. The pressure dropping in nano fluids is the main idea of the hybrid nano particles. It also known as the further improvement of hybrid nano fluids.

Nano technology is a science and art of nano particles. The nano scale reading is between 1 to 100000 is the width. Nano materials are tiny in size, surface area also very incredible per unit. These are very strong and less in weight.These are having 500 commercial products and it has $30 \%$ cosmetics and it has anti bacterial, bats, golf clubs. Foremost pure liquids, the thermal conductivity can be estimated by using the modified bridge man equation.

$\mathrm{k}=2.8\left(\mathrm{~N}_{\mathrm{A}} / \mathrm{v}\right)^{2 / 3} \mathrm{~K} \mathrm{U}$

Where $\mathrm{N}_{\mathrm{A}}=$ Avogadro's number

$=6.023 * 10^{23}$ molar program

$\mathrm{V}=$ molar volume

$\mathrm{k}=$ Boltzmann's constant

$=1.3807 * 10^{-23} \mathrm{~m}^{2} \mathrm{~kg} \mathrm{~s}^{-2} \mathrm{~K}^{-1}$

$\mathrm{U}=$ ultrasonic velocity

Revised Manuscript Received on November 06, 2019.

Sandeep Chinta, Department of Mechanical Engineering, Institute of Aeronautical Engineering, Dundigal, Hyderabad, India. Email: chintasunny2020@gmail.com

Sakkriga Mounika, Department of Mechanical Engineering, Institute of Aeronautical Engineering, Dundigal, Hyderabad, India. Email: mounica348@gmail.com

Aravind Reddy, Department of Mechanical Engineering, Institute of Aeronautical Engineering, Dundigal, Hyderabad, India. Email: aravindreddy1993@gmail.com

\subsection{COPPER OXIDE:}

This is a compound of two elements they are copper and oxygen.

\section{COPPER PROPERTIES:}

The melting point of copper is $1083.4+/-0.2^{0} \mathrm{c}$

boiling point $2567^{\circ} \mathrm{c}$

specific gravity $8.96\left(20^{\circ} \mathrm{c}\right)$

copper is reddish in colour and takes a bright metallic lustre. Greatest source of $\mathrm{cu}$ is minerals like chalcopyrite and bournite.

\subsection{BAMBOO LEAVES ASH}

The silica content in the bamboo leaves is more when compare to ground nut shell and sugarcane ash. Rice husk has the more silica content in that. In this paper we have to find out the silica content in the bamboo leaves by using that we can make the nano fluid.

\section{EXPERIMENTAL PROCEDURE}

\subsection{SYNTHESIS OF SILICA FROM BAMBOO LEAVES}

We can collect the bamboo leaves from bamboo tree and wash cleanly. There are no dust particles on that leaves. We should take 10 grams of bamboo leaves. We placed that bamboo leaves on hot plate and it is sintered at $900{ }^{0} \mathrm{c}$ for 7 hours. Later we get the ash from bamboo hot plate. That as is a full of dust particles. We can clear those particles. Later we add $1 \mathrm{M}$ of $\mathrm{NaOH}$ or sulphuric acid $\mathrm{H}_{2} \mathrm{SO}_{4}$ to that ash for clearing the dust particles. From that we take $1.77 \mathrm{grms}$ of ash for preparing nano fluid.

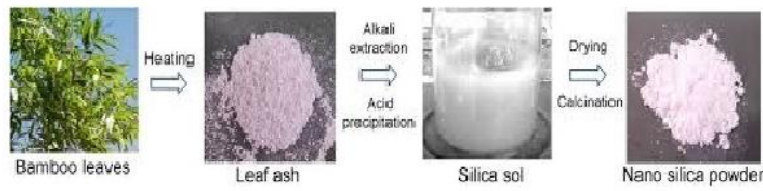

Pc 2.1 synthesis of silica from bamboo leaves The chemical equation for getting silica from bamboo leaves is

$$
\mathrm{SiO}_{2}\left(\text { ash) }+2 \mathrm{NaOH} \rightarrow \mathrm{Na}_{2} \mathrm{SiO}_{3}+\mathrm{H}_{2} \mathrm{O}\right.
$$

The chemical equation is

$$
\mathrm{Na}_{2} \mathrm{SiO}_{3}+\mathrm{H}_{2} \mathrm{SO}_{4} \rightarrow \mathrm{SiO}_{2}+\mathrm{Na}_{2} \mathrm{SO}_{4}+\mathrm{H}_{2} \mathrm{O}
$$




\section{Thermophysical Properties of Hybrid Nano Fluids}

\subsection{COPPER OXIDE (CuO) PREPARATION:}

A. For preparing the copper oxide we can take the above prepared nano fluid. We can mix up that fluid to the copper oxide through the particle size analyse machine. Also we mix the little bit of solution to that fluid. The $\mathrm{CuO}$ nano fluid is prepared by two step method. In single step it is synthesized by wet chemical process.

$$
\mathrm{CuCl}_{2}+2 \mathrm{NaOH}=\mathrm{CuO}+\mathrm{NaCl}+\mathrm{H}_{2} \mathrm{O}
$$

Mix up with ethylene glycol taking different concentrations of $\mathrm{CuO}$ nano liquids from 0.03 to 0.07 and ultra sonication is taking place for 35 minutes. It may be reduces the thermal conductivity. After that ultrasoniction method no nano particles are observed.

After mixing the nanofluid with copper we have to find out the acoustical properties. Like density, compressibility, intermolecular free length, ultrasonic velocity, intermolecular free length, thermo physical properties such as raos constant, wadas constant, thermal conductivity.

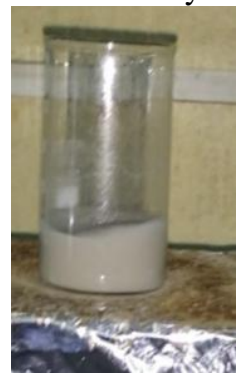

Pc 2.2 mixing of nano fluid with copper oxide

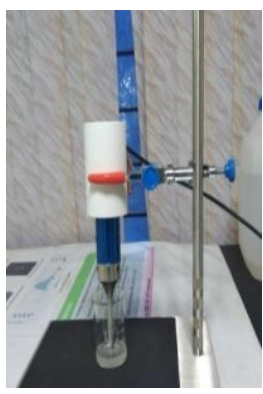

Pc 2.3 probe sonicator

\section{RESULTS AND DISCUSSION}

From the above content the final results are concluded that thermal and acoustical parameters of nano fluids of bamboo and copper oxide $(\mathrm{CuO})$.

1) $\mathrm{XRD}$ (x ray diffraction)

2) PSA (particle size analyser)

3) FTIR ( Fourier transform infrared spectroscopy)

4)SEM (scanning electron microscope)

\section{X-RAY DIFFRACTION}

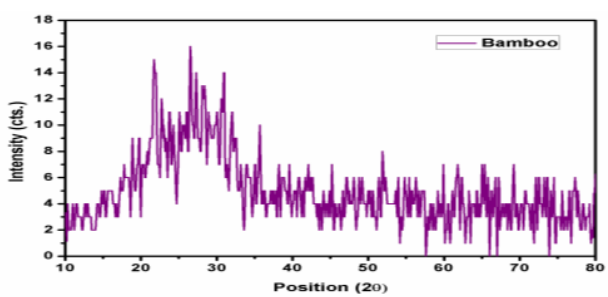

Pc 3.1 X-Ray diffraction graph of silica nano particles from bamboo leaf ash
After $x$ ray diffraction the particle of nano size is $25 \mathrm{~nm}$ and $\mathrm{SiO}_{2}$ is found

\section{PARTICLE SIZE ANALYSER}

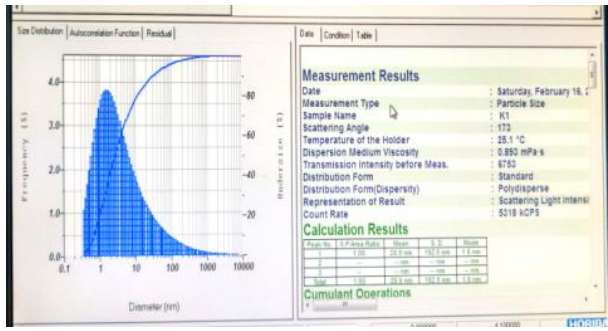

Pc 3.2 Particle size analyser of $\mathrm{SiO}_{2}$ nano particle of bamboo leaf

The size this nano particle is $25 \mathrm{~nm}$ this is a particle size when it is distributed also

\section{FTIRSPECTROSCOPY}

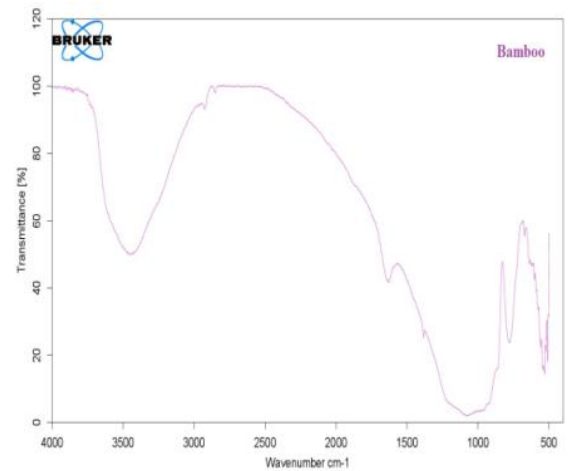

Pc 3.3 FTIR spectroscopy graph of silica nano particles from bamboo leaf

\section{ZETA POTENSIAL}

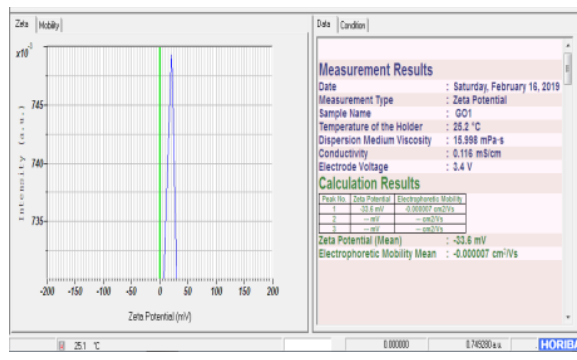

SEM

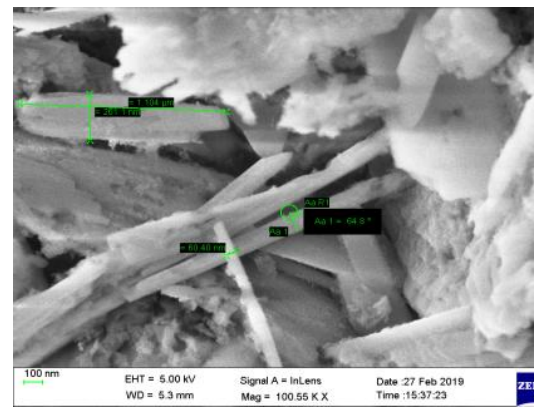

\section{CONCLUSIONS}

Studies of nano fluids reveals high thermal conductivities and heat transfer coefficients compared to those of conventional fluids. 
These characteristic features of nano fluids make them suitable for the next generation of flow and heat-transfer fluids.

Pioneering nano fluids research has inspired physicists, chemists, and engineers around the world. Producing silica from the bamboo leaves ash is beat way to produce high quantity of silica. $\mathrm{CuO}-\mathrm{SiO}_{2}$ it revels the acoustical parameters with the base fluid ethylene glycol

\section{.ACKNOWLEDGMENTS}

Authors give thanks to Prof. K. Venkateswara Rao, Head Centre for Nano Science \& Technology, JNTUH, Hyderabad, Prof. VVSH Harinadh Prasad, Head Mechanical Engieering, IARE and the research scholars from the centre for Nano Science, JNTUH to perform experimental work and to analyze the results.

\section{REFERENCES}

1. S. U. S. Choi, Y. I. Cho, and K. E. Kasza, Degradation effects of dilute polymer solutions on turbulent friction and heat transfer behavior, Journal of Non-Newtonian Fluid Mechanics, 41(1992), 289-307.

2. Ziye Ling, Zhenbin He, Tao Xu, Xiaoming Fang, Xuenong Gao and Zhengguo Zhang, Experimental and Numerical Investigation on Non-Newtonian Nanofluids Flowing in Shell Side of Helical Baffled Heat Exchanger Combined with Elliptic Tubes, 7 (2017) 48-50.

3. M. E. Burnett and S. Q. Wang, Current sunscreen controversies: Acritical review, Photo dermatology, Photo immunology\& Photo medicine, 27 (2011) 58-67.

4. K. Maier-Hauff, R. Rothe, and R. Scholz, Intracranial thermos therapy using magnetic nanoparticles combined with external beam radiotherapy: results of a feasibility study on patients with glioblastoma multiforme, Journal of Neuro-Oncology, 81 (2007) 53-60.

5. D. P. Kulkarni, D. K. Das, and R. S. Vajjha, Application of nanofluids in heating buildings and reducing pollution, Applied Energy, 86 (2009) 2566-2573.

6. L. V'ek'as, D. Bica, and M. V. Avdeev, Magnetic nanoparticles and concentrated magnetic nanofluids: synthesis, properties and some applications, China Particuology, 5 (2007) 43-49.

7. T. Sharma, A. L. M. Reddy, T. S. Chandra, and S. Rama prabhu, Development of carbon nanotubes and nanofluids based microbial fuel cell, International Journal of Hydrogen Energy, 33 (2008) 6749-6754.

8. L. SyamSundar a, Md. Hashim Farooky, Experimental thermal conductivity of ethylene glycol and water mixture based low volume concentration of $\mathrm{Al} 2 \mathrm{O} 3$ and $\mathrm{CuO}$ nanofluids, International Communications in Heat and Mass Transfer 41 (2013) 41-46.

9. M. Gupta, V. Singh, R. Kumar, and Z. Said, A review on thermophysical properties of nanofluids and heat transfer applications, Renewable \& Sustainable Energy Reviews, 74 (2017) 638-670.

10. Seow, Z. L. S., A. S. W. Wong, V. Thavasi, R. Jose, S. Ramakrishna and G.W. Ho, controlled synthesis and application of $\mathrm{ZnO}$ nanoparticles, nanorods and nanospheres in dye-sensitized solar cells. Nanotechnology, Vol. 20. 10. 1088/ 0957-4484/ 20/ 4/ 045604/ meta, 2008 .

\section{AUTHORS PROFILE}

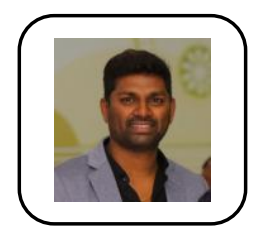

Dr. Ch.Sandeep, has graduate (B.Tech) in Mechanical Engineering, Post- Graduate (M.Tech) in Mechatronics from and Post Graduate Diploma (PGDENM) from University of Hyderabad. He awarded PhD degree from University of Hyderabad. Dr. Sandeep has 6 years of teaching and 5 years of research experience. He has published 10 research papers in reputed National/International Conferences and Journals. His areas of interest include Material Science, Renewable Energy, Nano Technology, Automation and Robotics.

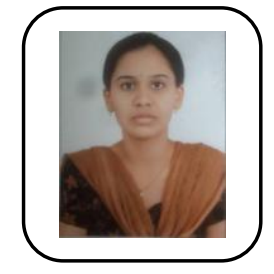

Ms. Sakkirga Mounika, graduate (B.Tech) in Mechanical Engineering, Pursuing Post- Graduate (M.Tech) in CAD/CAM from Institute of Aeronautical Engineering, Hyderabad. Her areas of interest include Material Science, Renewable Energy, Nano Technology.

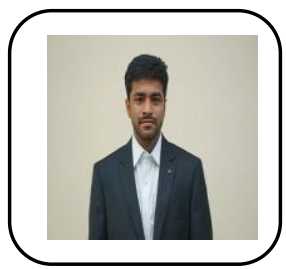

Mr. G. Aravind Reddy has done his masters from Osmania University in the field of Design for Manufacture. His research works carried out in additive manufacturing and nanomaterials and mainly focuses on $3 \mathrm{~d}$ printing works related to biomedical operations in software and prototype developing. 